\title{
Changes in the expenditure for psychopharmaca in the last 20 years in Greece
}

Sotiris Koupidis

From $1^{\text {st }}$ International Congress on Neurobiology and Clinical Psychopharmacology and European

Psychiatric Association Conference on Treatment Guidance

Thessaloniki, Greece. 19-22 November 2009

The increased cost of psychopharmacological treatment in combination with the need for the transformation of Mental Health care with closing of big mental asylums and expansion of community-oriented services makes the need to evaluate the whole process. The analysis of the economic data from the years 2000-2009 for the mental health hospital of Corfu in comparison with data from the National Statistical Agency and coding according to the International Classification of Health Accounts (ICHA) suggests that the cost increased in spite of the fact that the number of patients decreased dramatically. The concomitant increase in the psychotherapeutic and psychosocial interventions did not cause any reduction in pharmacological costs.

It seems important to include economic indices in the evaluation of psychiatric transformation and also to apply international systems for the registration and assessment of health accounts. Also, the issue of generic drugs arises as of prime importance.

Published: 22 April 2010

doi:10.1186/1744-859X-9-S1-S21

Cite this article as: Koupidis: Changes in the expenditure for

psychopharmaca in the last 20 years in Greece. Annals of General

Psychiatry 2010 9(Suppl 1):S21.
Submit your next manuscript to BioMed Central and take full advantage of:

- Convenient online submission

- Thorough peer review

- No space constraints or color figure charges

- Immediate publication on acceptance

- Inclusion in PubMed, CAS, Scopus and Google Scholar

- Research which is freely available for redistribution

Submit your manuscript at www.biomedcentral.com/submit
C Biomed Central 